How to Cite: Raiymbekov, Y.B., Besterekov, U., Abdurazova, P.A., Nazarbek, U.B., \& Pochitalkina, I.A. (2021). Recovery of used acetic acid via sulfuric acid. Bulletin of the University of Karaganda - Chemistry, 104(4), 149-162. https://doi.org/10.31489/2021Ch4/149-162

\author{
Y.B. Raiymbekov ${ }^{1 *}$, U. Besterekov $^{1}$, P.A. Abdurazova ${ }^{1}$, \\ U.B. Nazarbek ${ }^{1}$, I.A. Pochitalkina ${ }^{2}$ \\ ${ }^{I}$ M.Auezov South Kazakhstan University, Shymkent, Kazakhstan; \\ ${ }^{2}$ Mendeleev University of Chemical Technology of Russia, Moscow, Russia \\ (*Corresponding author's e-mail: eplusr@bk.ru)
}

\title{
Recovery of used acetic acid via sulfuric acid
}

\begin{abstract}
Kazakhstan has a huge phosphate raw material base, where the basis is made up of micro-grained phosphate ores of the Karatau basin. The depletion of reserves of high-quality commercial ores leads to the search for new methods of using the enrichment and sorting of low-grade technogenic ores, one of which is phosphatesiliceous slates. The presented study was carried out in two stages: at the first stage, phosphate-siliceous shales were enriched by the acetic acid method, regime technological parameters, kinetic and thermodynamic regularities of the process were determined. At the second stage of the research a method for recycling used acetic acid during the enrichment of low-grade phosphate-siliceous slates is proposed. In this case, sulfuric acid was chosen as the regenerating agent of acetic acid. The reliability of the performed studies was proved by the use of modern complex research methods: scanning electron microscopy, Energy Dispersive X-Ray and X-Ray difraction analyses. To determine the course of a particular reaction, a thermodynamic analysis was performed using modern HSC 6.0 software. The kinetic data are determined by calculation. The obtained experimental data were subjected to statistical analysis (Chaddock scale, standard deviation, coefficient of determination). The mechanism of interaction of an acetate solution with sulfuric acid is illustratively described. In conclusion, the sulfuric acid method is suitable for the regeneration of applied acetic acid. In this case, a by-product is formed in the form of calcium sulfate. This product can be used as a building binder (confirmed by the protocol of the "National Center of Expertise" of the Republic of Kazakhstan).
\end{abstract}

Keywords: acid recovery, acetic acid, low-grade phosphorites, beneficiation, sulfuric acid, phosphatesiliceous slates, Chaddock scale, calcium sulfate.

\section{Introduction}

The globalization process of the economy and ensuring the sustainable development of all sectors of the national economy requires timely and effective solutions to the problems accumulated by mankind. The steadily increasing consumption of mineral raw materials ensures the dynamic development of the economy and society of many countries of the world, including Kazakhstan.

The Republic of Kazakhstan is one of the countries in the world that has large deposits of phosphorite in the Karatau phosphorite-bearing basin. When extracting phosphorites, an open method is usually used and it is always accompanied by the formation of various wastes. The main by-products of open-pit mining of phosphorites in the Karatau basin are phosphate-siliceous shales. The approximate volume of accumulated waste is about 40 million tons. This indicator is growing every year, while high-grade $\left(23-27 \% \mathrm{P}_{2} \mathrm{O}_{5}\right)$ and medium-grade $\left(20-23 \% \mathrm{P}_{2} \mathrm{O}_{5}\right)$ deposits of phosphorites are being depleted [1,2]. Scientists attribute this type of waste to the technogenic resources of the Karatau basin [3].

According to the lithological composition, this type of waste belongs to a variety of clay-siliceous shales with an interlayer of carbonate-siliceous and pelitomorphic carbonate-siliceous phosphorites with phosphate-clay-siliceous shales [3-4]. Its composition is dominated by clay compounds $\left(\mathrm{SiO}_{2}\right)$ and one-anda-half oxides $\left(\mathrm{Fe}_{2} \mathrm{O}_{3}, \mathrm{Al}_{2} \mathrm{O}_{3}\right)$, which complicate the enrichment process [5].

With an increase in the consumption of phosphorus-containing products [6], the reserves of rich and ordinary phosphorites are being depleted, and in a few years industrialists may face the problem of an acute shortage of high-quality raw materials. In this regard, the strategy for the development of the mineral resource base should be based on the rational use of the identified resources and their timely reproduction.

The world reserves of phosphorites are dominated by hard-to-enrich ores of carbonate, siliceouscarbonate and carbonate-siliceous composition [7, 8]. There are various methods for enriching low-grade phosphorites: flotation, calcination, magnetic separation $[9,10]$. One of the promising methods is the use of dilute organic acids, the so-called chemical enrichment. Organic acids with slow heating have the ability to dissolve dolomites and calcites in the composition of phosphorite, while not affecting the phosphate part of 
the raw material [11]. The use of organic acids is relevant for countries where the production of phosphoruscontaining products is one of the main sectors of the economy. So, scientists from China [11, 12], Egypt [13], Uzbekistan [14], Pakistan [15, 16], and Russia [17, 18] conducted similar studies. In their works, organic acids of various types were used. However, in many studies [11-18], the use of acetic acid as the main reagent that dissolves carbonate minerals well is particularly noted. The chemistry of the reaction of acetic acid with carbonates can be represented as follows:

$$
\begin{aligned}
2 \mathrm{CH}_{3} \mathrm{COOH}+\mathrm{CaCO}_{3} & =\left(\mathrm{CH}_{3} \mathrm{COO}\right)_{2} \mathrm{Ca}+\mathrm{CO}_{2}+\mathrm{H}_{2} \mathrm{O} \\
2 \mathrm{CH}_{3} \mathrm{COOH}+\mathrm{MgCO}_{3} & =\left(\mathrm{CH}_{3} \mathrm{COO}\right)_{2} \mathrm{Mg}+\mathrm{CO}_{2}+\mathrm{H}_{2} \mathrm{O}
\end{aligned}
$$

As can be seen from the reaction equation, acetic acid reacts with carbonates to form salts of calcium and magnesium acetates. The dissolved carbonates in the form of an acetate salt remain in the solution, and, accordingly, the content of total $\mathrm{P}_{2} \mathrm{O}_{5}$ increases in the insoluble part.

In addition, we have determined that potassium and aluminum-containing compounds in the composition of phosphorite also actively interact with acetic acid:

$$
\begin{gathered}
2 \mathrm{CH}_{3} \mathrm{COOH}+\mathrm{K}_{2} \mathrm{O}=2 \mathrm{KCH}_{3} \mathrm{COO}+\mathrm{H}_{2} \mathrm{O} \\
6 \mathrm{CH}_{3} \mathrm{COOH}+\mathrm{Al}_{2} \mathrm{O}_{3}=2 \mathrm{Al}\left(\mathrm{CH}_{3} \mathrm{COO}\right)_{3}+3 \mathrm{H}_{2} \mathrm{O}
\end{gathered}
$$

Although these studies indicate that the process of enriching low-grade phosphorites has been successfully carried out, there is also a problem of disposing of the acetate solution. This issue is relevant, since a large amount of dilute acetic acid is spent during enrichment (liquid/solid ratio $=8: 1,5: 1,3: 1$ ). Consequently, a considerable volume of the solution is formed. The authors propose various methods of disposal: the use of the ion exchange method, regeneration with hydrochloric acid and hydrofluoric acid [19]. Also, in the future, the sulfuric acid can be applied to obtain calcium sulfate [20].

All of the above studies are only at the theoretical level. Until now, no experimental studies have been conducted on the recovery of acetic acid, so there is an acute lack of comprehensive data on this problem.

Thus, the aim of the research is to study the process of acetic acid recovery with the use of sulfuric acid and the production of calcium sulfate. The given experimental data are new and can serve for further development of research in the field of enrichment of low-grade phosphorites with organic acids.

The studies were conducted in two stages. At the first stage, the process of enrichment of phosphatesiliceous shales of the Zhanatas deposit (Karatau basin) with acetic acid was carried out. The optimal operating parameters are established: the highest yield of $\mathrm{P}_{2} \mathrm{O}_{5}$ is $21 \%$ at $30{ }^{\circ} \mathrm{C}, 15 \mathrm{~min}$ and liquid/solid ratio $=1: 3$ [21]. Kinetic regularities are determined, a thermodynamic analysis of the acetic acid enrichment process is carried out. During the enrichment process, an acetate solution was obtained, which must be disposed of or returned to the process. Considering this issue, the second stage of the study provides the results.

\section{Experimental}

The recovery process of acetic acid was studied in the laboratory using experimental lab equipment (Fig. 1): an acetate solution and sulfuric acid were mixed at temperatures of 333, 348, and $363 \mathrm{~K}$ on a magnetic stirrer, to which a $\mathrm{pH}$ meter I-160MI was attached to observe changes during the process. The mixing time varied from $15 \mathrm{~min}$ to $45 \mathrm{~min}$. The suspension was filtered on a Buchner funnel with a constant dilution of $0.06 \mathrm{MPa}$. The sediment on the filter was dried at $110^{\circ} \mathrm{C}$ to a constant weight.

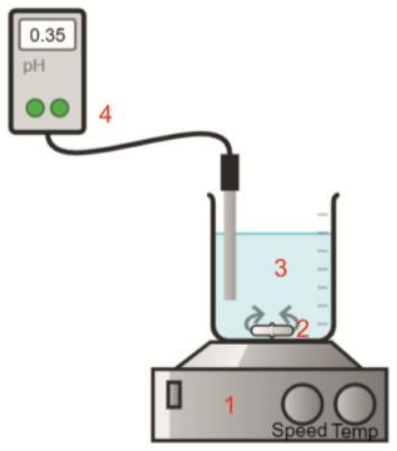

1 - magnetic stirrer; 2 - magnetic stir bar; 3 - solution of acetates and sulfuric acid; $4-\mathrm{pH}$-meter

Figure 1. Experimental lab equipment 
The study of the element-weight composition and structural features of the source material and the resulting product was implemented on a scanning electron microscope JSM-64901 V [22].

The X-ray difraction (XRD) analysis of the feedstock and the resulting product was performed on the D8 Advance (Bruker), $\alpha$-Cu apparatus. The processing of the obtained diffractogram data and the calculation of interplane distances were carried out applying EVA software. The samples were decoded and the phases were searched using the Search / match program and the PDF-2 powder diffractometric data base.

The multifunctional software package HSC 6.0 was used to conduct a thermodynamic analysis of the acetic acid recovery process, taking into account the phase changes of the initial components and final products, with the calculation of changes in the enthalpy, entropy, Gibbs energy, and the logarithm of the equilibrium constant.

The calculation of the reaction rate of the acetic acid recovery process was performed according to the formula:

$$
\partial=\frac{\Delta n}{V \Delta \tau}
$$

where: $\Delta n$ - change in the amount of moles of starting substances, mol; $V$ - volume of the mixture, 1 ; $\Delta \tau$ - time, min.

The study's results of the kinetic regularities of the acetic acid recovery are processed using the Pavlyuchenko equation [23]:

$$
1-(1-\alpha)^{1 / 3}=\kappa \cdot \sqrt{\tau} .
$$

This equation is typical for the processes that begin on the entire surface but the progress of the reaction into the depth of the particle depends on the thickness of the layer formed by the reaction products through which the reagent diffuses. This equation describes the processes, the limiting stage of which is diffusion.

The calculation of the apparent activation energy of the process $\left(E_{\text {app }}\right)$ is graphically determined from the dependence $\ln \kappa=f\left(\frac{1}{T}\right)$, when the value of the reaction rate constant is known at certain process temperatures.

$E_{\text {app }}$ determined by the formula:

$$
E_{\text {app }}=8.314 \cdot \operatorname{tg}_{\varphi}(\mathrm{J} / \mathrm{mol}) .
$$

Kinetic data were subjected to statistical processing (standard deviation and correlation analysis) $[24,25]$.

\section{Results and Discussion}

Characteristics of the acetate solution

The acetate solution obtained during the enrichment of low-grade phosphate-siliceous shales was subjected to evaporation to study its element-weight composition. The evaporated acetate solution is presented in the form of a white crystalline substance that is highly soluble in water. It has a faint smell of vinegar. The results are shown in Figure 1 and in Table 1.

Element-weight composition of the acetate solution

\begin{tabular}{|c|c|c|}
\hline Element & Weight, $\%$ & In terms of oxides, $\%$ \\
\hline $\mathrm{C}$ & 26.77 & - \\
\hline $\mathrm{O}$ & 45.88 & - \\
\hline $\mathrm{Mg}$ & 0.59 & 0.97 \\
\hline $\mathrm{Al}$ & 0.21 & 0.39 \\
\hline $\mathrm{Si}$ & 0.62 & 1.32 \\
\hline $\mathrm{S}$ & 0.68 & 1.7 \\
\hline $\mathrm{Ca}$ & 24.15 & 33.78 \\
\hline $\mathrm{Mn}$ & 0.32 & 0.41 \\
\hline $\mathrm{Fe}$ & 0.79 & 1.12 \\
\hline
\end{tabular}



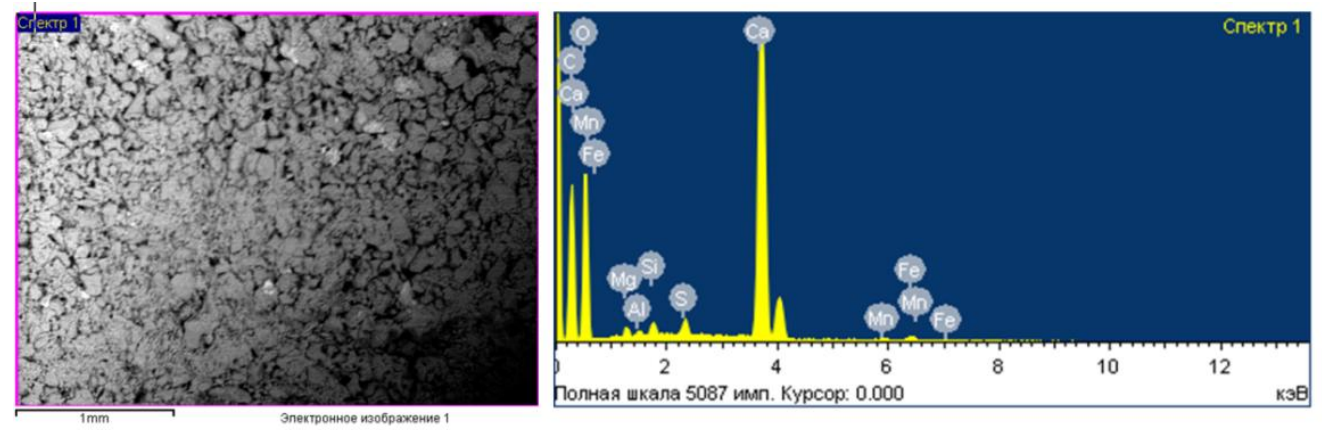

Figure 2. SEM image and EDX analysis of evaporated acetate solution

The data of the element-weight composition illustrate the predominant presence of calcium compounds. There are also impurity elements in the form of magnesium, sulfur, silicon, iron, and manganese, which were transferred during the acetic acid leaching of low-grade phosphate-siliceous shales by reactions 1-4.

For a more detailed study of the composition of the acetate solution, the method of XRD analysis was used. The results are represented in Figure 3 and in Table 2.

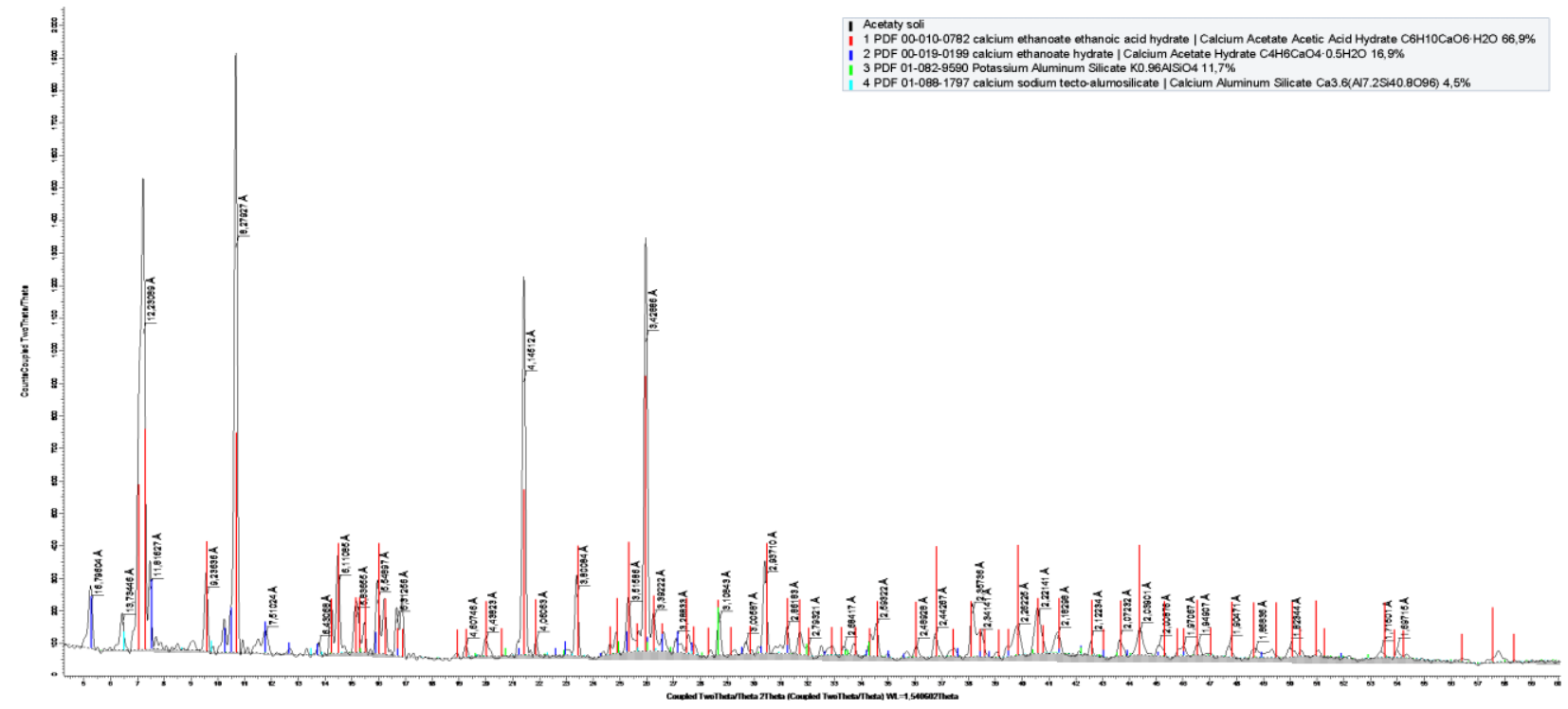

Figure 3. XRD image of evaporated acetate solution

Table 2

XRD decryption of evaporated acetate solution

\begin{tabular}{|c|l|c|c|}
\hline Pattern \# & \multicolumn{1}{|c|}{ Compound Name } & Formula & S-Q \\
\hline PDF 00-010-0782 & $\begin{array}{l}\text { Calcium ethanoate ethanoic acid hydrate | Calcium Acetate } \\
\text { Acetic Acid Hydrate }\end{array}$ & $\mathrm{C}_{6} \mathrm{H}_{10} \mathrm{CaO}_{6} \cdot \mathrm{H}_{2} \mathrm{O}$ & $66.9 \%$ \\
\hline PDF 00-019-0199 & Calcium ethanoate hydrate | Calcium Acetate Hydrate & $\mathrm{C}_{4} \mathrm{H}_{6} \mathrm{CaO}_{4} \cdot 0.5 \mathrm{H}_{2} \mathrm{O}$ & $16.9 \%$ \\
\hline PDF 01-082-9590 & Potassium Aluminum Silicate & $\mathrm{K}_{0.96} \mathrm{AlSiO}_{4}$ & $11.7 \%$ \\
\hline PDF 01-088-1797 & $\begin{array}{l}\text { Calcium sodium tecto-alumosilicate | Calcium Aluminum } \\
\text { Silicate }\end{array}$ & $\mathrm{Ca}_{3.6}\left(\mathrm{Al}_{7.2} \mathrm{Si}_{4.8} \mathrm{O}_{96}\right)$ & $4.5 \%$ \\
\hline
\end{tabular}

The data of the XRD analysis clearly demonstrate the presence of the main compounds in the composition of the evaporated acetate solution. The main compound is calcium acetate hydrate in the amount of $83.8 \%$. There is also the presence of impurity compounds of potassium-aluminosilicates and calciumaluminosilicates. 
Reaction mechanism and thermodynamic analysis

The chemistry of used acetic acid recovery process with sulfuric acid can be represented as follows:

$$
\begin{gathered}
\mathrm{Ca}\left(\mathrm{CH}_{3} \mathrm{COO}\right)_{2}+\mathrm{H}_{2} \mathrm{SO}_{4}=2 \mathrm{CH}_{3} \mathrm{COOH}+\mathrm{CaSO}_{4} \downarrow \\
\mathrm{Mg}\left(\mathrm{CH}_{3} \mathrm{COO}\right)_{2}+\mathrm{H}_{2} \mathrm{SO}_{4}=2 \mathrm{CH}_{3} \mathrm{COOH}+\mathrm{MgSO}_{4} \\
2 \mathrm{Al}\left(\mathrm{CH}_{3} \mathrm{COO}\right)_{3}+3 \mathrm{H}_{2} \mathrm{SO}_{4}=6 \mathrm{CH}_{3} \mathrm{COOH}+\mathrm{Al}_{2}\left(\mathrm{SO}_{4}\right)_{3} \\
2 \mathrm{KCH}_{3} \mathrm{COO}+\mathrm{H}_{2} \mathrm{SO}_{4}=2 \mathrm{CH}_{3} \mathrm{COOH}+\mathrm{K}_{2} \mathrm{SO}_{4}
\end{gathered}
$$
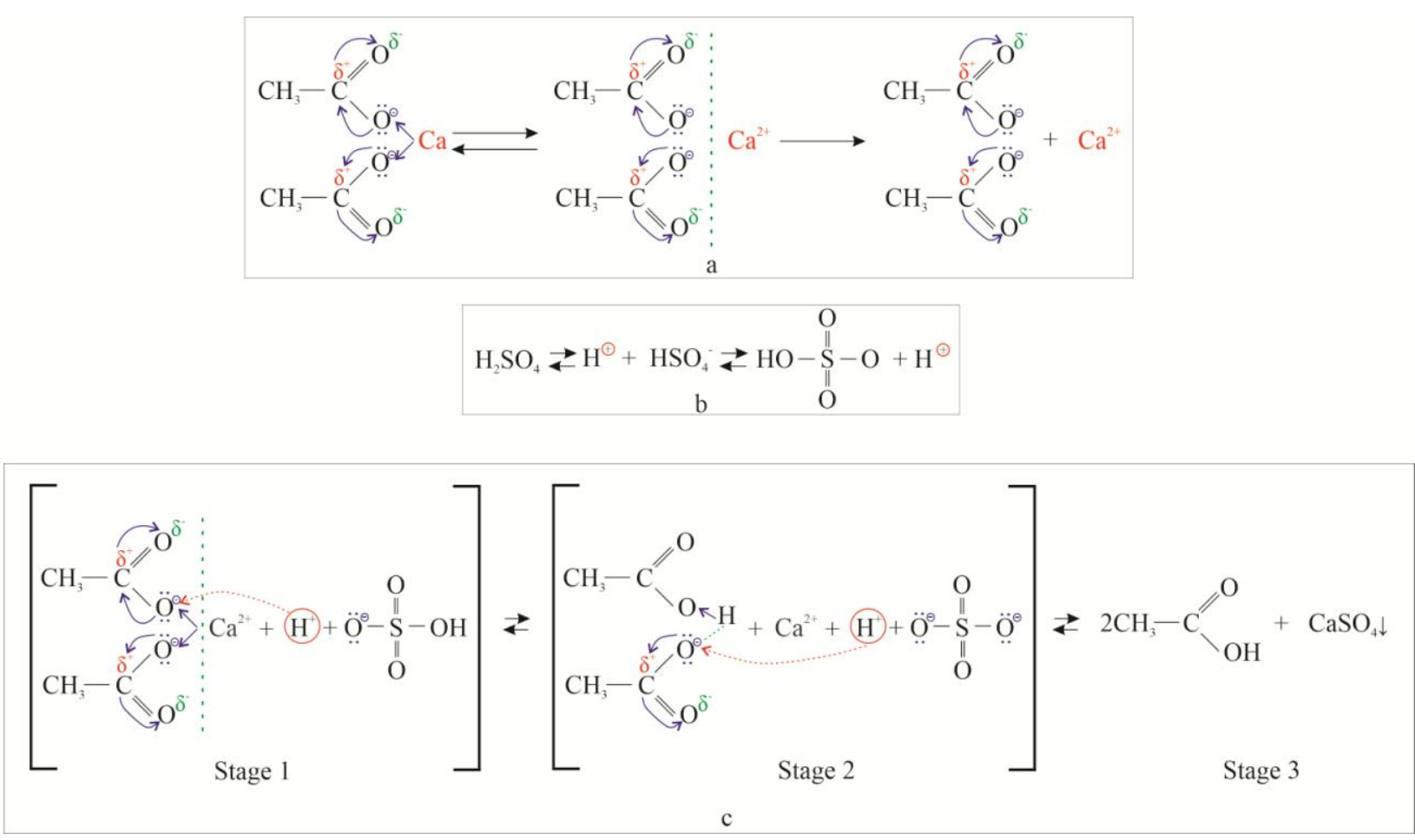

$a$ - calcium acetate dissociation mechanism; $b$ - sulfuric acid dissociation mechanism; $c$ - calcium acetate and sulfuric acid mechanism reaction

Figure 4. Reaction mechanism

Interacting molecule (substrate) — the carboxylic acid salt dissociates as follows (Fig. 4a): the stability (hence the acidic properties) of the carboxylate anion is explained by the delocalization of the negative charge in 2 oxygen atoms due to $\rho, \pi$-pairing (fusion). Concentrated $\mathrm{H}_{2} \mathrm{SO}_{4}$ is a very strong oxidizing agent [26], especially when heated (Fig. 4b). The concentration of sulfuric acid determines the rate and direction of the sulfating process, as well as the mass of the sulfate reagent necessary for its implementation, since the reaction occurs and the acid concentration decreases (as a result of diluting it with reaction water). This leads to an increase in the possibility of acid dissociation of $\mathrm{H}_{2} \mathrm{SO}_{4}$ and a decrease in the concentration of sulfonated particles.

At Stage 1 (Fig. $4 c$ ), the electrophilic center $\left(\mathrm{S}_{\mathrm{E}}\right)$ is a carbon atom of the carboxyl group, in the presence of which carboxylic acids and their functional derivatives enter into nucleophilic substitution reactions. At Stage 2, the main center-an oxotope with one pair of electrons is protonated at the catalysis stage in nucleophilic substitution reactions. At Stage 3, the oxotope forms a salt after protonation, displacing the calcium cation and the formation of weak acetic acid. All stages of the reaction are reversible. A detailed illustration of the process of interaction of an acetate solution and sulfuric acid is shown in Figure 5.

During the reaction 5-8, calcium sulfate precipitates, and the remaining formed compounds, such as magnesium, aluminum, and potassium sulfate, are soluble and thus will be present in the solution.

To determine the ability of a particular reaction to proceed, a thermodynamic analysis was carried out taking into account the phase changes of the initial components and final products, with the calculation of changes in the enthalpy, entropy, Gibbs energy, and the logarithm of the equilibrium constant. The thermodynamic characteristics of the processes were determined in the temperature range of 333, 348, and $363 \mathrm{~K}$. The results of calculating the thermodynamic characteristics as a function of the temperature in the proposed reaction are represented in Table 3. 


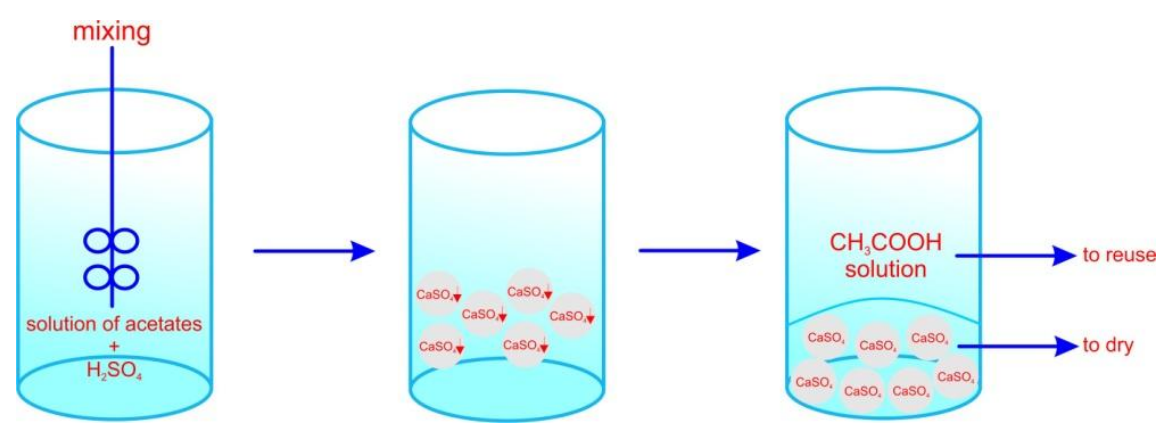

Figure 5. Schematic illustration of the process

Table 3

Thermodynamic parameters of the reactions (5-8)

\begin{tabular}{|c|c|c|c|c|c|}
\hline $\mathrm{T}, \mathrm{K}$ & $\begin{array}{c}\Delta \mathrm{H}^{0}, \\
\mathrm{~kJ} / \mathrm{mol}\end{array}$ & $\begin{array}{c}\Delta \mathrm{S}^{0} \\
\mathrm{~J} /(\mathrm{mol} \cdot \mathrm{K})\end{array}$ & $\begin{array}{c}\Delta \mathrm{G}^{0}, \\
\mathrm{~kJ} / \mathrm{mol}\end{array}$ & $\mathrm{K}$ & $\log (\mathrm{K})$ \\
\hline \multicolumn{6}{|c|}{$\mathrm{Ca}\left(\mathrm{CH}_{3} \mathrm{COO}\right)_{2}+\mathrm{H}_{2} \mathrm{SO}_{4}=2 \mathrm{CH}_{3} \mathrm{COOH}+\mathrm{CaSO}_{4} \downarrow$} \\
\hline 333 & -69.207 & 221.692 & -141.031 & $2.740 \mathrm{E}+022$ & 22.438 \\
\hline 348 & -64.295 & 236.120 & -146.465 & $9.686 \mathrm{E}+021$ & 21.986 \\
\hline 363 & -59.308 & 250.149 & -150.112 & $4.004 \mathrm{E}+021$ & 21.603 \\
\hline \multicolumn{6}{|c|}{$\mathrm{Mg}\left(\mathrm{CH}_{3} \mathrm{COO}\right)_{2}+\mathrm{H}_{2} \mathrm{SO}_{4}=2 \mathrm{CH}_{3} \mathrm{COOH}+\mathrm{MgSO}_{4}$} \\
\hline 333 & 30.789 & 285.047 & -64.131 & $1.150 \mathrm{E}+010$ & 10.061 \\
\hline 348 & 35.627 & 299.255 & -68.514 & $1.927 \mathrm{E}+010$ & 10.285 \\
\hline 363 & 40.532 & 313.055 & -73.107 & $3.317 \mathrm{E}+010$ & 10.521 \\
\hline \multicolumn{6}{|c|}{$2 \mathrm{Al}\left(\mathrm{CH}_{3} \mathrm{COO}\right)_{3}+3 \mathrm{H}_{2} \mathrm{SO}_{4}=6 \mathrm{CH}_{3} \mathrm{COOH}+\mathrm{Al}_{2}\left(\mathrm{SO}_{4}\right)_{3}$} \\
\hline 333 & 222.513 & 1210.239 & -180.496 & $2.066 \mathrm{E}+028$ & 28.315 \\
\hline 348 & 212.167 & 1179.832 & -198.415 & $6.087 \mathrm{E}+029$ & 29.784 \\
\hline 363 & 203.133 & 1154.406 & -215.916 & $1.181 \mathrm{E}+031$ & 31.072 \\
\hline \multicolumn{6}{|c|}{$2 \mathrm{KCH}_{3} \mathrm{COO}+\mathrm{H}_{2} \mathrm{SO}_{4}=2 \mathrm{CH}_{3} \mathrm{COOH}+\mathrm{K}_{2} \mathrm{SO}_{4}$} \\
\hline 333 & -132.494 & -33.184 & -121.444 & $1.126 \mathrm{E}+019$ & 19.051 \\
\hline 348 & -133.098 & -34.961 & -120.931 & $1.423 \mathrm{E}+018$ & 18.153 \\
\hline 363 & -133.432 & -35.905 & -120.399 & $2.121 \mathrm{E}+017$ & 17.327 \\
\hline
\end{tabular}

The values of $\Delta \mathrm{G}^{0}$ in the studied temperature range are in the negative region, and this indicates the thermodynamic probability of reactions 5-8. From the comparison of the values of $\Delta \mathrm{G}^{0}$ reactions, it follows that from a thermodynamic point of view, the probability of reactions occurring at these temperatures changes in the following sequence: $\mathrm{Al}\left(\mathrm{CH}_{3} \mathrm{COO}\right)_{3}>\mathrm{Ca}\left(\mathrm{CH}_{3} \mathrm{COO}\right)_{2}>\mathrm{KCH}_{3} \mathrm{COO}>\mathrm{Mg}\left(\mathrm{CH}_{3} \mathrm{COO}\right)_{2}$. In this case, reactions 5 and 8 are exothermic, which follows from the negative values of $\Delta \mathrm{H}^{0}$.

\section{Kinetic regularities}

Based on the above reactions, temperatures in the range of 333,348 , and $363 \mathrm{~K}$ were selected for effective recovery of acetic acid. The process time is 15,30 , and 45 minutes. The reaction rate was calculated according to the formula (1). The results of the experiments are illustrated in Table 4.

The data in Table 4 designate the reaction rate slows down with increasing temperature and time. An increase in temperature negatively affects the value of $\alpha$-the degree of expenditure of sulfuric acid, since this value decreases. This means the remaining part of the sulfuric acid did not have time to react with the acetates in the solution.

Statistical processing of experimental data showed that at $333 \mathrm{~K}$, the relationship between the studied features is direct, the closeness (strength) of the connection on the Chaddock scale is high, the average approximation error (characterizes the adequacy of the regression model) is $5.0 \%$. Data at 348 and $363 \mathrm{~K}$, the dependence between the studied features is direct, the closeness (strength) of the connection on the Chaddock scale is functional, the average approximation error is $1.8 \%$ and $2.1 \%$, respectively. 
The obtained experimental data

\begin{tabular}{|c|c|c|c|c|c|c|}
\hline Time, min & $\mathrm{pH}$ & $\mathrm{C}, \mathrm{mol} / 1$ & $\begin{array}{c}\text { The degree } \\
\text { of expenditure, } \alpha\end{array}$ & $v, \mathrm{~mol} / \mathrm{l} \cdot \min$ & Standard deviation & $\begin{array}{c}\text { Coefficient } \\
\text { of determination }\end{array}$ \\
\hline \multicolumn{7}{|c|}{$333 \mathrm{~K}$} \\
\hline $15 \mathrm{~min}$ & 0.117 & 0.76383 & 42.23 & 0.07436 & 3.02 & \multirow{3}{*}{0.975} \\
\hline $30 \mathrm{~min}$ & 0.129 & 0.74190 & 76.30 & 0.06718 & 3.18 & \\
\hline $45 \mathrm{~min}$ & 0.150 & 0.70794 & 95.46 & 0.05603 & 2.66 & \\
\hline \multicolumn{7}{|c|}{$348 \mathrm{~K}$} \\
\hline $15 \mathrm{~min}$ & 0.169 & 0.67622 & 25.92 & 0.04564 & 1.52 & \multirow{3}{*}{0.998} \\
\hline $30 \mathrm{~min}$ & 0.172 & 0.67236 & 50.40 & 0.04437 & 2.32 & \\
\hline $45 \mathrm{~min}$ & 0.177 & 0.66484 & 71.40 & 0.04191 & 2.15 & \\
\hline \multicolumn{7}{|c|}{$363 \mathrm{~K}$} \\
\hline $15 \mathrm{~min}$ & 0.190 & 0.64534 & 20.17 & 0.03551 & 0.83 & \multirow{3}{*}{0.997} \\
\hline $30 \mathrm{~min}$ & 0.197 & 0.63530 & 36.60 & 0.03222 & 1.91 & \\
\hline $45 \min$ & 0.203 & 0.62661 & 49.99 & 0.02934 & 1.89 & \\
\hline
\end{tabular}

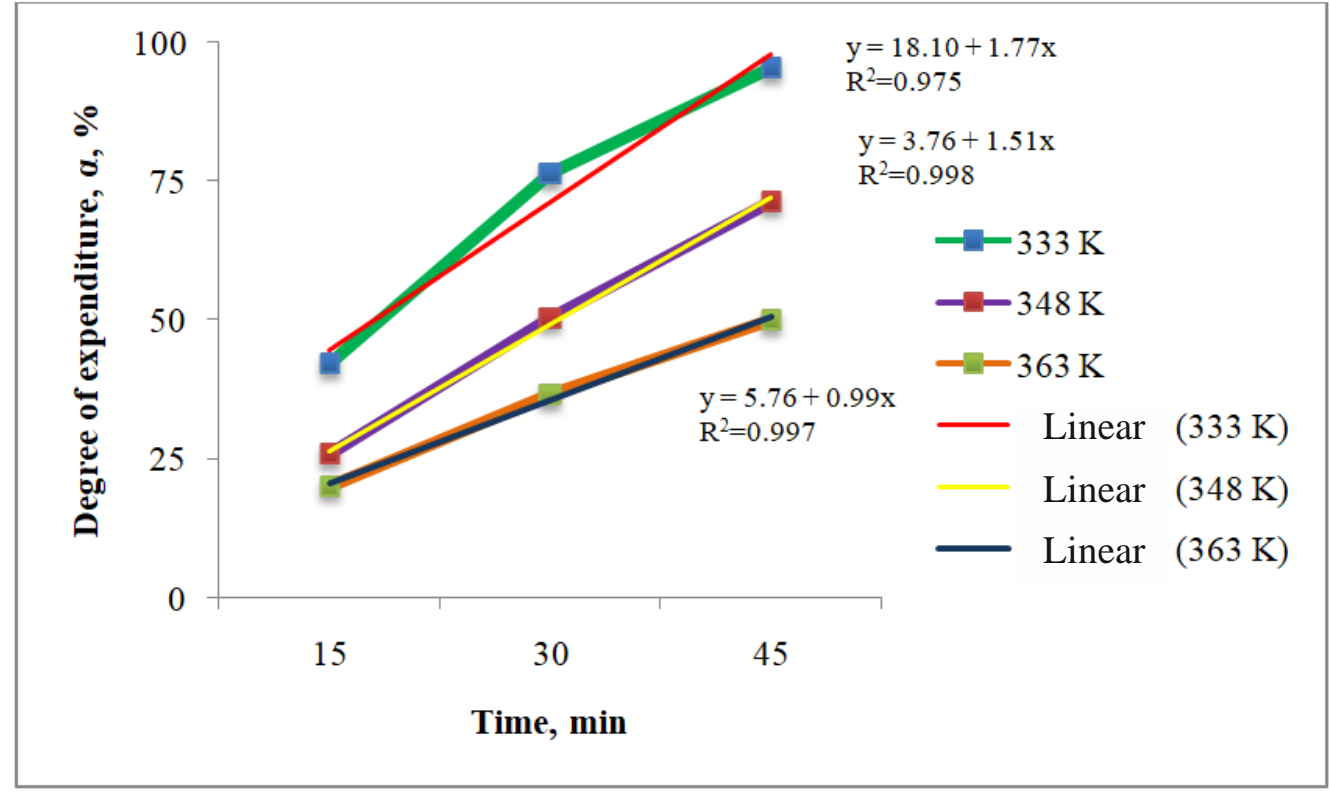

Figure 6. Dependence of sulfuric acid expenditure degree on time

The highest degree of expenditure of sulfuric acid, as presented in Table 4 and Figure 6 , is $333 \mathrm{~K}$ and $45 \mathrm{~min}$. This means that not all the sulfuric acid has been reacted and an excess of acid remains in the solution. The unreacted free sulfuric acid will interact with the formed soluble sulfates of magnesium, aluminum, and potassium:

$$
\begin{gathered}
\mathrm{MgSO}_{4}+\mathrm{H}_{2} \mathrm{SO}_{4}=\mathrm{Mg}\left(\mathrm{HSO}_{4}\right)_{2} \downarrow \\
\mathrm{Al}_{2}\left(\mathrm{SO}_{4}\right)_{3}+3 \mathrm{H}_{2} \mathrm{SO}_{4}=2 \mathrm{Al}\left(\mathrm{HSO}_{4}\right)_{3} \downarrow \\
\mathrm{K}_{2} \mathrm{SO}_{4}+\mathrm{H}_{2} \mathrm{SO}_{4}=2 \mathrm{KHSO}_{4} \downarrow
\end{gathered}
$$

According to the reaction 9-10, insoluble compounds of magnesium, aluminum, and potassium hydrosulfate are formed, which precipitate without passing into solution.

The experimentally found kinetic parameters are processed by the Pavlyuchenko method applying the equation (2).

The effect of temperature and time on the degree of expenditure $(\alpha)$ during the recovery of acetic acid and the results of processing experimental data in relation to the Pavlyuchenko equation are shown in Table 5 . 
Results of experimental data processing

\begin{tabular}{|c|c|c|c|c|c|}
\hline$\alpha$ (shares of 1) & $1-\alpha$ & $\sqrt[3]{1-\alpha}$ & $1-\sqrt[3]{1-\alpha}$ & $\tau, \min$ & $\sqrt{\tau}$ \\
\hline \multicolumn{7}{|c|}{$\mathrm{T}=333 \mathrm{~K}$} \\
\hline 0.4223 & 0.5777 & 0.832851 & 0.167149 & 15 & 3.87298 \\
\hline 0.7630 & 0.2370 & 0.618846 & 0.381154 & 30 & 5.47722 \\
\hline 0.9546 & 0.0454 & 0.356740 & 0.643260 & 45 & 6.70820 \\
\hline \multicolumn{7}{|c|}{$\mathrm{T}=348 \mathrm{~K}$} \\
\hline 0.2592 & 0.7408 & 0.904830 & 0.095170 & 15 & 3.87298 \\
\hline 0.5040 & 0.4960 & 0.791578 & 0.208422 & 30 & 5.47722 \\
\hline 0.7140 & 0.2860 & 0.658853 & 0.341147 & 45 & 6.70820 \\
\hline \multicolumn{7}{|c|}{$\mathrm{T}=363 \mathrm{~K}$} \\
\hline 0.2017 & 0.7983 & 0.927660 & 0.072340 & 15 & 3.87298 \\
\hline 0.3660 & 0.6340 & 0.859072 & 0.140928 & 30 & 5.47722 \\
\hline 0.4999 & 0.5001 & 0.793753 & 0.206247 & 45 & 6.70820 \\
\hline
\end{tabular}

Based on the data in Table 5, a dependency graph $1-(1-\alpha)^{1 / 3}=f(\sqrt{\tau})$ is constructed:

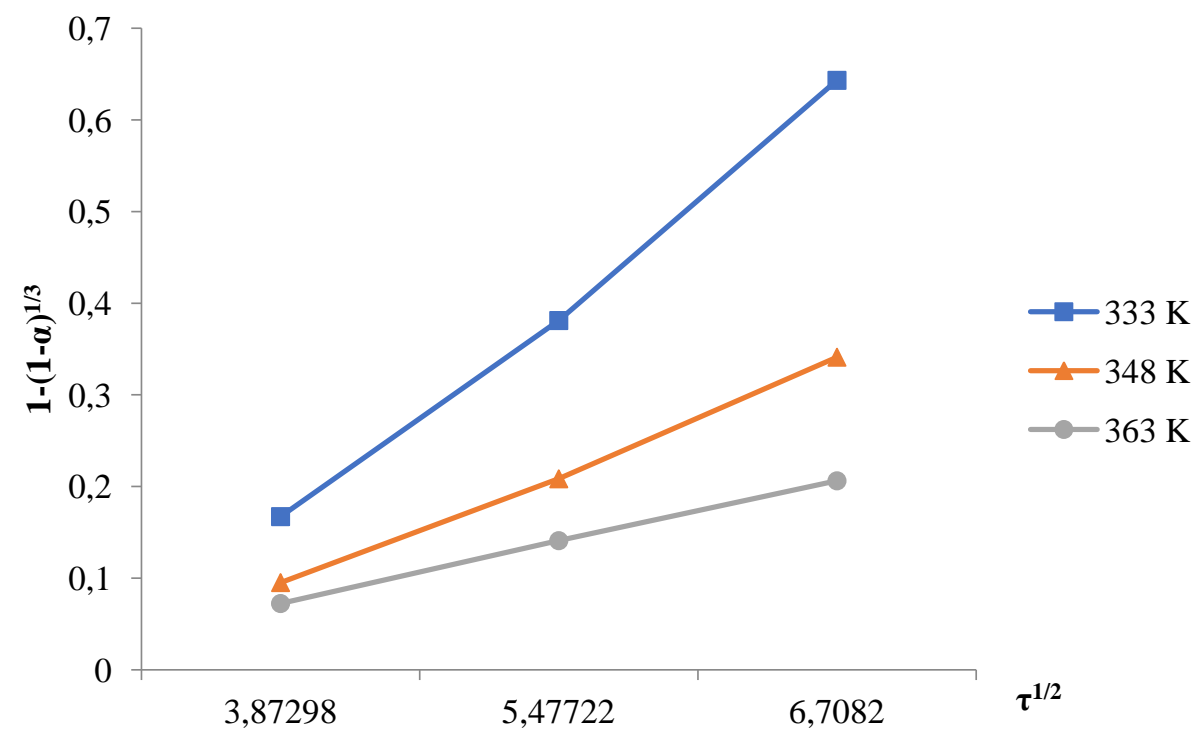

Figure 7. Dependency graph $1-(1-\alpha)^{1 / 3}=f(\sqrt{\tau})$

The reaction rate constants are found by the tangent of the angle of the straight lines to the abscissa axis shown in Figure 7:

- at $333 \mathrm{~K}, \operatorname{tg}_{\varphi 1}=\mathrm{k}_{1}=0.1175827$;

- at $348 \mathrm{~K}, \operatorname{tg}_{\varphi 2}=\mathrm{k}_{2}=0.0315797$;

- at $363 \mathrm{~K}, \operatorname{tg}_{\varphi 3}=\mathrm{k}_{3}=0.0096065$.

The "apparent" activation energy of the recovery process is found by the graphical method. For these purposes, a dependency graph $\ln k=f\left(\frac{1}{T}\right)$ is constructed (Fig. 8). 


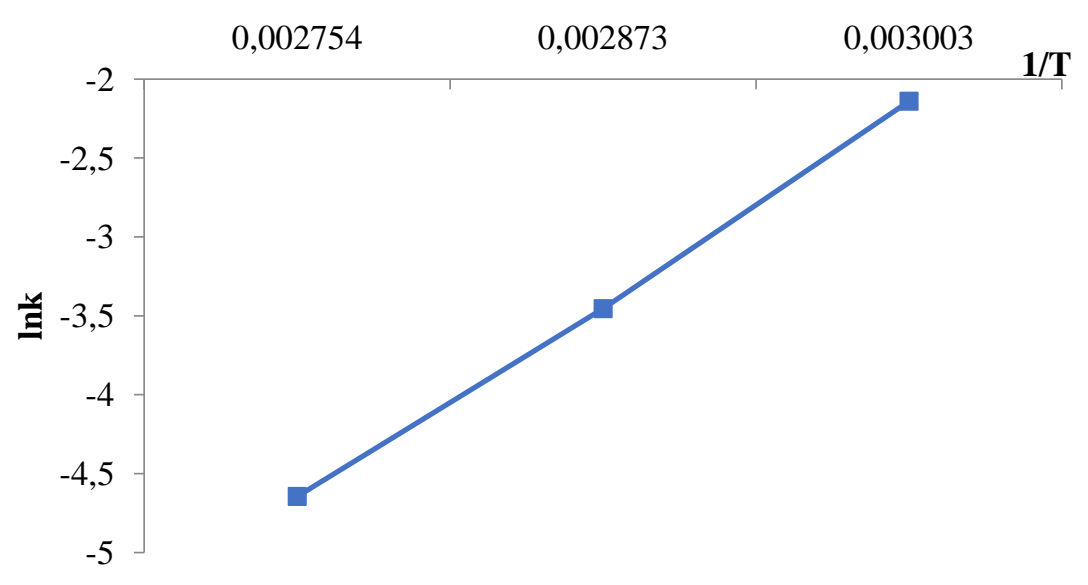

Figure 8. Dependency graph $\ln k=f\left(\frac{1}{T}\right)$

Based on Figure 8 and using the formula (3), the "pparent" activation energy of the process was calculated. For the studied process, the $\mathrm{E}_{\text {app }}$ was $59.65 \mathrm{~kJ} / \mathrm{mol}$. The found value of the apparent activation energy allows concluding that the studied process takes place in the intra-diffusion region [23].

Characteristics of the resulting product

During the mixing of the acetate solution and sulfuric acid, a white crunocrystalline precipitate and a solution of acetic acid were formed. The precipitate was pure calcium sulfate (gypsum). For the analysis, the resulting calcium sulfate was dried isothermically at a temperature of $110 \mathrm{C}$ to a constant weight. Dried calcium sulfate was subjected to SEM and XRD analysis (Table 6, Fig. 9).

\section{Element-weight composition of the formed sediment}

\begin{tabular}{|c|c|c|}
\hline Element & Weight, $\%$ & In terms of oxides, $\%$ \\
\hline $\mathrm{O}$ & 48.03 & - \\
\hline $\mathrm{Mg}$ & 0.29 & 0.48 \\
\hline $\mathrm{Al}$ & 0.58 & 1.09 \\
\hline $\mathrm{Si}$ & 0.54 & 1.15 \\
\hline $\mathrm{S}$ & 22.33 & 55.82 \\
\hline $\mathrm{K}$ & 0.32 & 0.38 \\
\hline $\mathrm{Ca}$ & 27.91 & 39.04 \\
\hline
\end{tabular}

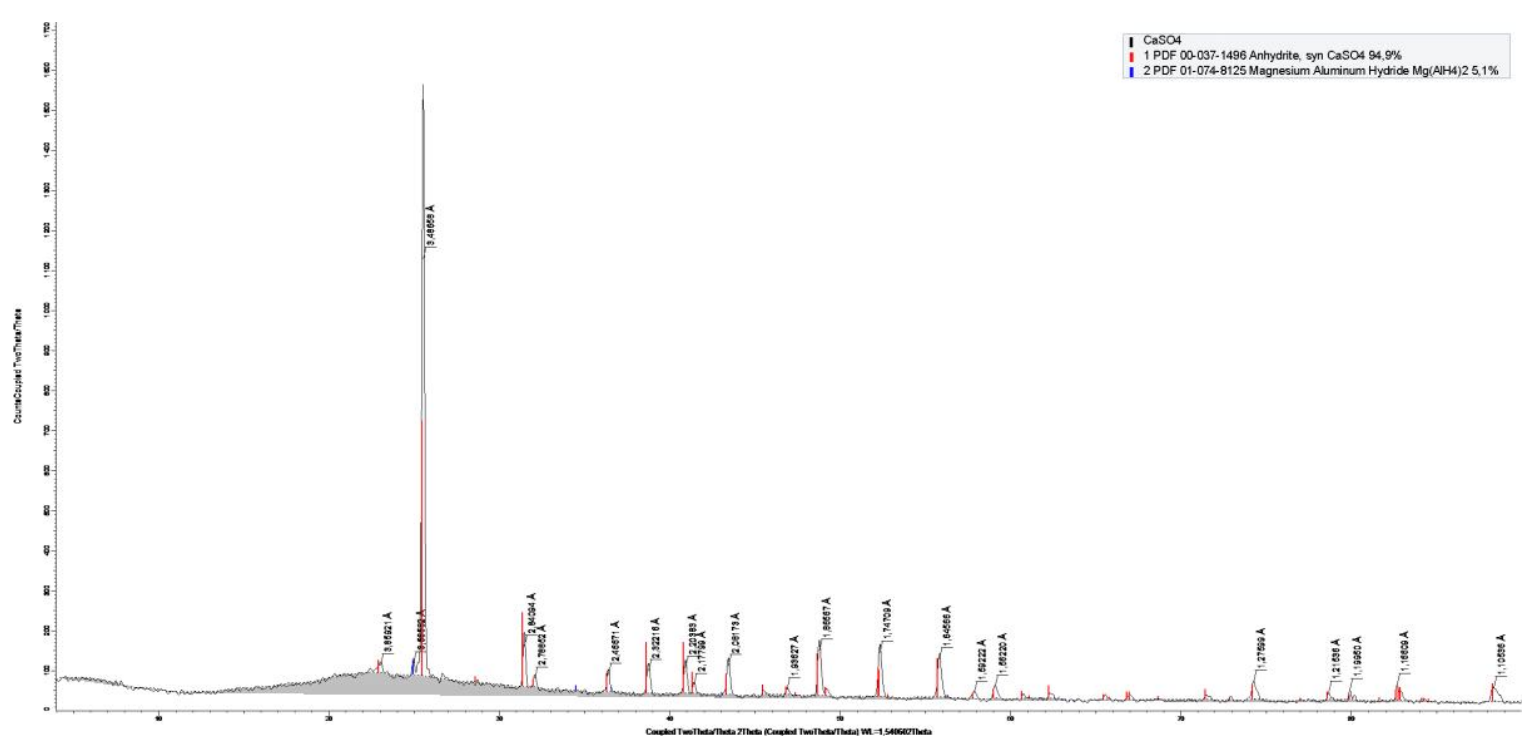

Figure 9. XRD analysis of sediment 
As mentioned above, in addition to calcium sulfate, there were compounds in the form of magnesium, aluminum, and potassium hydrosulfate in the sediment. The data of element-weight and XRD analysis proved the presence of these compounds in the composition of the sediment. From the XRD analysis, it was found out the main structural compound in the sediment was calcium sulfate - $94.9 \%$. The remaining $5.1 \%$ was probably occupied by the magnesium aluminum hydride compound. The white crystalline product was acidic with a $\mathrm{pH}=0.159$, since it contained a small amount of free sulfuric acid.

The resulting by-product in the form of calcium sulfate can be used as a building material (gypsum) [27]. To determine the suitability and use, a radiological analysis was carried out in the "National Center of Expertise". The samples were examined in accordance with the requirements of regulatory documents, in particular "GOST 30108-94. Building materials and elements. Determination of specific activity of natural radioactive nuclei" at the Progres BG gamma-spectrometric equipment. The results are shown in Table 7.

Table 7

Results of measurements of specific radioactivity

\begin{tabular}{|c|c|c|c|c|}
\hline Sample name & $\begin{array}{c}\text { Specific effective } \\
\text { activity, Bk/kg }\end{array}$ & $\begin{array}{c}\text { Permissible level of } \\
\text { specific effective } \\
\text { activity, Bq/kg }\end{array}$ & $\begin{array}{c}\text { Construction } \\
\text { material class }\end{array}$ & $\begin{array}{c}\text { Terms of use } \\
\text { of building materials }\end{array}$ \\
\hline Calcium Sulfate & $10 \pm 2$ & 370 & 1 & $\begin{array}{c}\text { Use in residential and } \\
\text { public buildings under } \\
\text { construction and re- } \\
\text { construction }\end{array}$ \\
\hline
\end{tabular}

As the measurement results show, the specific effective activity is within the permissible level and corresponds to the conditions of use in residential and public buildings under construction and being reconstructed. The results of the study were confirmed by Protocol No. 18-pl/s / RO-21-0-1170 from 03.06.2021 "National Center of Expertise".

\section{Conclusions}

The obtained research results demonstrate the suitability of the sulfuric acid method of recovery of an acetate solution for reuse in the enrichment of low-grade phosphorites. The obtained and statistically processed experimental data illustrate the operating technological parameters that are the temperature at $60{ }^{\circ} \mathrm{C}$ and the time of $45 \mathrm{~min}$. It was at these indicators that the highest degree of consumption of sulfuric acid was achieved for the complete precipitation of calcium sulfate. Thermodynamic analysis revealed the regularity of the reaction. The calculated "apparent" activation energy of the heterogeneous process was $59.65 \mathrm{~kJ} / \mathrm{mol}$. This means the process takes place in the intradiffusion region. The resulting by-product in the form of calcium sulfate can be used as a building material (gypsum). The presented results are complementary to the information about the acid enrichment of low-grade phosphorites.

\section{References}

1 Елкондиева Г.Б. Каратауский бассейн - крупнейшая фосфатная сырьевая база Евразии / Елкондиева Г.Б. // Фосфатное сырье: производство и переработка: материалы Междунар. науч.-практ. конф. (17 мая 2012 г.). - М., 2012. — С. 21-30.

2 Перфильева Н.Н. Фосфорный путь / Н.Н. Перфильева. - Тараз: ТОО Казфосфат, 2018. - [Электронный ресурс]. Режим доступа: http://www.kpp.kz/upload/kf_video_files/Fosfor_way.pdf.

3 Киперман Ю.А. Фосфаты в ХХІ веке: моногр. / Ю.А. Киперман. — Тараз: ТОО Казфосфат, 2006. — [Электронный ресурс]. Режим доступа: http://www.kpp.kz/upload/kf_video_files/fosfati_XXI.pdf.

4 Glenn C.R., Phosphorites // Sedimentology. Encyclopedia of Earth Science. — Berlin: Springer, Heidelberg, 1978. — 255 p. https://doi.org/10.1007/3-540-31079-7

5 СТ РК 2213-2012. Сырье измельченное фосфатное Каратау. Технические условия, Комитет технического регулирования и метрологии Министерства промышленности и новых технологий Республики Казахстан. — Астана, 2012.

6 Schroder J.J. Sustainable Use of Phosphorus / J.J. Schroder, D. Cordell, A.L. Smit, A. Rosemarin. — Wageningen: Plant Research International, 2010. - $140 \mathrm{p}$.

7 Van Kauwenbergh S.J. World Phosphate Rock Reserves and Resources / S.J. Van Kauwenbergh. — IFDC: Muscle Shoals, Alabama, 2010. - $60 \mathrm{p}$ 
8 Garside M. Global phosphate rock reserves by country 2020. - [Electronic resourse]. Access mode: https://www.statista.com/statistics/681747/phosphate-rock-reserves-by-country/.

9 Komar Kawatra S. Beneficiation of Phosphate Ore. Society for Mining, Metallurgy, and Exploration / S. Komar Kawatra, J.T. Carlson. — Englwood, 2013. - 168 p.

10 Ptacek P. Mining and Beneficiation of Phosphate Ore, Apatites and their Synthetic Analogues — Synthesis, Structure, Properties and Applications / P. Ptacek. — London: IntechOpen, 2016. — 514 p. https://doi.org/10.5772/62215

11 Fei X. Research on Enrichment of $\mathrm{P}_{2} \mathrm{O}_{5}$ from Low-Grade Carbonaceous Phosphate Ore via Organic Acid Solution / X.Fei, Zh.Jie, Ch.Jiyan, W.Jianrui, W.Lin // J. Anal. Methods Chem. — 2019. — P. 7. https://doi.org/10.1155/2019/9859580

12 Patent 104445112A. People's Republic of China. Method for recycling phosphate ores by using acid leaching method / W. Zhang, J. Wang, Y. Zhang. — Guizhou University. Publ. 25.03.2015.

13 Bakry A.R. Upgrading of Abu-Tartur calcareous phosphate via selective leaching by organic acids / A.R. Bakry, N.A. Abdelfattah, A.B. Farag // Int. J. Eng. Res. - 2015. - No.6. - P. 57-64. https://www.ijser.org/researchpaper/ Upgrading-of-Abu-Tartur-calcareous-phosphate-via-selective-leaching-by-organic-acids.pdf

14 Seitnazarov A. Beneficiation of High-Calcareous Phosphorites of Central Kyzylkum with Organic Acid Solutions / A.Seitnazarov, S. Namazov, B. Beglov // J. Chem. Technol. Metall. - 2014. - No. 49. - P.383-390. https://dl.uctm.edu/journal/node/j2014-4/JCTM_2014_4_Beneficiation\%20of\%20high-calcareous\%20phosphorites\%20of\%20central $\% 20$ kyzylkum\%20with\%20organic\%20acid\%20s.pdf

15 Zafar I.Z. Beneficiation of low grade carbonate-rich phosphate rocks using dilute acetic acid solution // Fertilizer Research. - 1993. - No. 34. - P. 173-180. https://doi.org/10.1007/BF00750112

16 Zafar I.Z. Selective leaching of calcareous phosphate rock in formic acid: Optimisation of operating conditions / I.Z. Zafar, M.M. Anwar, P.W. Pritchard // Min. Eng. — 2006. — No. 19. - P. 1459-1461. https://doi.org/10.1016/j.mineng.2006.03.006

17 Патент 2097139С1. Российская Федерация. Способ обогащения карбонатсодержащего фосфатного сырья / Йелстаун Корпорейшн Н.В. (NL). Опубл. 27.11.1997.

18 Патент 469664A1. Советский Союз. Способ обогащения фосфоритов / Г.О. Григорян. Опубл. 05.05.1975.

19 Zafar I.Z. A New Route for the Beneficiation of Low Grade Calcareous Phosphate Rocks / I.Z. Zafar, M.M. Anwar, P.W. Pritchard // J. Fert. Res. — 1996. — No. 44. — P. 133-142. https://doi.org/10.1007/bf00750803

20 Ashraf M. Reaction kinetics and mass transfer studies in selective leaching of low-grade calcareous phosphate rock: $\mathrm{PhD}$ thesis: Chemistry / M. Ashraf. — Multan, Pakistan, 2010. — 194 p.

21 Raiymbekov Y. Beneficiation of phosphate-siliceous slates via acetic acid / Y. Raiymbekov, U. Besterekov, P. Abdurazova, U. Nazarbek, I. Petropavlovskiy // International Journal of Chemical Reaction Engineering. — 2021. — Vol. 19, Iss. 11. — P. 11871195. https://doi.org/10.1515/ijcre-2021-0071

22 Reed S.J.B. Electron Microprobe Analysis and Scanning Electron Microscopy in Geology. - University of Cambridge, Cambridge, 2005. — 189 p. https://doi.org/10.1017/CBO9780511610561

23 Вольдман Г.М. Теория гидрометаллургических процессов / Г.М. Вольдман, А.Н. Зеликман // — М.: Интермет Инжиниринг, 2003. - $464 \mathrm{c}$.

24 Hatcher L. Advanced Statistics in Research: Reading, Understanding, and Writing Up Data Analysis Results / L. Hatcher. Shadow Finch Media LLC, Michigan, 2013. - 644 p.

25 Martin W.E. Quantitative and Statistical Research Methods: From Hypothesis to Results 1st Edition / W.E. Martin, K.D. Bridgmon. — Jossey-Bass, 2012. — 496 p.

26 Davenport W.G. Sulfuric Acid Manufacture. Analysis, Control and Optimization / W.G. Davenport, M.J. King // Elsevier Science, 2006. - $413 \mathrm{p}$.

27 Guerra-Cossío M.A. Calcium sulfate: an alternative for environmentally friendly construction / M.A. Guerra-Cossío, J.R.G. Lopez, A.A. Zaldivar-Cadena // 2nd International Conference on Bio-based Building Materials \& 1st Conference on ECOlogical valorisation of GRAnular and FIbrous materials, Clermont-Ferrand, France, 2017. - P. 1-6. https://doi.org/10.26168/icbbm2017.37

\section{Е.Б. Райымбеков, У. Бестереков, П.А. Абдуразова, У.Б. Назарбек, И.А. Почиталкина}

\section{Қолданылған сірке қышқылын күкірт қышқылымен регенерациялау}

Қазақстанда Қаратау бассейнінің шағын түйіршікті фосфат кендерінің негізін құрайтын орасан зор фосфат шикізат базасы бар. Жоғары сапалы тауарлық кен қорларының сарқылуы төмен сұрыпты техногендік кендерді байыту мен сұрыптаудың жаңа әдістерін іздеуге әкеледі, олардың бірі фосфаткремнийлі қатпар тастар болып табылады. Зерттеу екі кезеңде жүргізілді: бірінші кезеңде фосфаткремнийлі қатпар тастар сірке қышқылы әдісі арқылы байытылды, режимдік технологиялық параметрлер, үрдістің кинетикалық және термодинамикалық заңдылықтары анықталды. Осы мақалада зерттеудің екінші кезеңі қарастырылған: онда төмен сұрыпты фосфат-кремнийлі қатпар тастарды байыту кезінде пайдаланылған сірке қышқылын кәдеге жарату әдісі ұсынылған. Бұл жағдайда күкірт қышқылы сірке қышқылының қалпына келтіретін агенті ретінде таңдалды. Жүргізілген зерттеулердің 
шынайылығы қазіргі заманғы кешенді зерттеу әдістерін қолданумен негізделеді: растрлық электронды микроскопия, EDX және XRD талдау. Нақты реакцияның жүру мүмкіндігін анықтау үшін қазіргі заманғы HSC 6.0 бағдарламалық жасақтамасын қолдана отырып, термодинамикалық талдау жүргізілді. Кинетикалық деректер есептеу жолымен анықталды. Алынған эксперименттік мәліметтер статистикалық талдаудан өтті (Чеддок шкаласы, стандартты ауытқу, анықтау коэффициенті). Ацетат ерітіндісінің күкірт қышқылымен әрекеттесу механизмі суреттелген. Зерттеу нәтижелері пайдаланылған сірке қышқылын қалпына келтіруге күкірт қышқылы әдісінің жарамдылығы туралы қорытынды жасауға мүмкіндік береді. Бұл жағдайда кальций сульфаты түрінде жанама өнім пайда болады. Бұл өнімді құрылыс материалы ретінде пайдалануға болады (ҚР «Ұлттық сараптама орталығы» хаттамасымен расталған).

Кілт сөздер: қышқылды алу, сірке қышқылы, төмен сұрыпты фосфориттер, байыту, күкірт қышқылы, фосфат-кремнийлі қатпар тастар, Чеддок шкаласы, кальций сульфаты.

\section{Е.Б. Райымбеков, У. Бестереков, П.А. Абдуразова, У.Б. Назарбек, И.А. Почиталкина}

\section{Регенерация использованной уксусной кислоты серной кислотой}

Казахстан располагает огромной фосфатной сырьевой базой, где основу составляют микрозернистые фосфатные руды Каратауского бассейна. Истощение запасов качественных товарных руд приводит к поискам новых методов использования обогащения и сортировки низкосортных техногенных руд, одним из которых являются фосфатно-кремнистые сланцы. Представленное исследование было выполнено в два этапа: на первой стадии фосфатно-кремнистые сланцы обогащались посредством уксуснокислотного метода, были определены режимные технологические параметры, кинетические и термодинамические закономерности процесса. В статье рассмотрен второй этап исследования, где предложен метод утилизации использованной уксусной кислоты при обогащении низкосортных фосфатнокремнистых сланцев. В этом случае серная кислота была выбрана в качестве регенерирующего агента уксусной кислоты. Достоверность выполненных исследований обоснована применением современных комплексных методов исследований: растровой электронной микроскопии, EDX- и XRD-анализа. Для определения протекания конкретной реакции был проведен термодинамический анализ с помощью современного програмного обеспечения HSC 6.0. Кинетические данные получены расчетным путем. Экспериментальные данные были подвергнуты статистическому анализу (шкала Чеддока, стандартное отклонение, коэффициент детерминации). Иллюстративно описан механизм взаимодействия ацетатного раствора с серной кислотой. Результаты исследований позволяют сделать вывод о пригодности сернокислотного метода для регенерации использованной уксусной кислоты. При этом образуется побочный продукт в виде сульфата кальция, который можно применять в качестве строительного вяжущего материала (подтвержден Протоколом Национального центра экспертизы Республики Казахстан).

Ключевые слова: извлечение кислоты, уксусная кислота, низкосортные фосфориты, обогащение, серная кислота, фосфатно-кремнистые сланцы, шкала Чеддока, сульфат кальция.

\section{References}

1 Elkondieva, G.B. (2012). Karatauskii bassein - krupneishaia fosfatnaia syrevaia baza Evrazii [The Karatau basin is the largest phosphate resource base in Eurasia]. Proceedings from Phosphate raw materials: production and processing: Mezhdunarodnaia nauchno-prakticheskaia konferentsiia - International scientific and practical conference (17, May, 2012). (pp. 21-30). Moscow [in Russian].

2 Perfileva, N.N. (2018). Fosfornyi put [Phosphorus pathway]. Taraz: Kazphosphate LLC. Retrieved from http://www.kpp.kz/upload/kf_video_files/Fosfor_way.pdf [in Russian].

3 Kiperman, Yu.A. (2006). Fosfaty v XXI veke [Phosphates in the XXI century]. Taraz: Kazphosphate LLC. Retrieved from http://www.kpp.kz/upload/kf_video_files/fosfati_XXI.pdf [in Russian].

4 Glenn, C.R. (1978). Phosphorites. Sedimentology. Encyclopedia of Earth Science. Berlin: Springer. https://doi.org/10.1007/3540-31079-7

5 Standart Respubliki Kazahstan 2213-2012. Syre izmelchennoe fosfatnoe Karatau. Tehnicheskie usloviia [Standard Republic of Kazakhstan 2213-2012. Raw materials are crushed phosphate Karatau. Technical conditions]. (2012). Astana: Committee of Technical Regulation and Metrology of the Ministry of Industry and New Technologies of the Republic of Kazakhstan [in Russian].

6 Schroder, J.J., Cordell, D., Smit, A.L. \& Rosemarin, A. (2010). Sustainable Use of Phosphorus. Wageningen, Netherlands: Plant Research International.

7 Van Kauwenbergh, S.J. (2010). World Phosphate Rock Reserves and Resources. Muscle Shoals, Alabama, USA: IFDC.

8 Garside, M. (2021). Global phosphate rock reserves by country 2020. Retrieved from: https://www.statista.com/statistics/681747/phosphate-rock-reserves-by-country/. 
9 Komar Kawatra, S., \& Carlson, J.T. (2013). Beneficiation of Phosphate Ore. Society for Mining, Metallurgy, and Exploration. USA: Englwood.

10 Ptacek, P. (2016). Mining and Beneficiation of Phosphate Ore, Apatites and their Synthetic Analogues - Synthesis, Structure, Properties and Applications. London: IntechOpen. https://doi.org/10.5772/62215

11 Fei, X., Jie, Zh., Jiyan, Ch., Jianrui, W. \& Lin, W. (2019). Research on Enrichment of $\mathrm{P}_{2} \mathrm{O}_{5}$ from Low-Grade Carbonaceous Phosphate Ore via Organic Acid Solution. J. Anal. Methods Chem., 7. https://doi.org/10.1155/2019/9859580

12 Zhang, W., Wang, J. \& Zhang, Y. (2015). People's Republic of China Patent No. 104445112A. Guizhou: Guizhou University.

13 Bakry, A.R., Abdelfattah, N.A., \& Farag, A.B. (2015). Upgrading of Abu-Tartur calcareous phosphate via selective leaching by organic acids. Int. J. Eng. Res., 6, 57-64. https://www.ijser.org/researchpaper/Upgrading-of-Abu-Tartur-calcareous-phosphatevia-selective-leaching-by-organic-acids.pdf

14 Seitnazarov, A., Namazov, S., \& Beglov, B. (2014). Beneficiation of High-Calcareous Phosphorites of Central Kyzylkum with Organic Acid Solutions, J. Chem. Technol. Metall. 49, 383-390. Retrieved from: https://dl.uctm.edu/journal/node/j20144/JCTM_2014_4_Beneficiation\%20of\%20high-calcareous\%20phosphorites\%20of\%20central\%20kyzylkum\%20with\%20organic $\% 20$ acid\%20s.pdf

15 Zafar, I.Z. (1993). Beneficiation of low grade carbonate-rich phosphate rocks using dilute acetic acid solution. Fertilizer Research, 34, 173-180. https://doi.org/10.1007/BF00750112

16 Zafar, I.Z., Anwar, M.M., \& Pritchard, P.W. (2006). Selective leaching of calcareous phosphate rock in formic acid: Optimisation of operating conditions. Min. Eng., 19, 1459-1461. https://doi.org/10.1016/j.mineng.2006.03.006

17 Potashnik, B.A., Avakjan, Z.A., \& Karavajko, G.I. (1997). Sposob obogashcheniia karbonatsoderzhashchego fosfatnogo syria [Method for enrichment of carbonate-containing phosphate raw materials]. Patent No. 2097139C1. Rossiiskaia Federatsiia Russian Federation Patent No. 2097139C1. Moscow: Russia, Russian Agency for Patents and Trademarks [in Russian].

18 Grigoryan, G.O. (1975). Sposob obogashcheniia fosforitov [Phosphate enrichment method]. Patent No. 469664A1. Sovetskii Soiuz - Soviet Union Patent No. 469664A1. Moscow: Soviet Union, State Committee of the Council of Ministers of the USSR for Inventions and Discoveries [in Russian].

19 Zafar, I.Z., Anwar, M.M., \& Pritchard, P.W. (1996). A New Route for the Beneficiation of Low Grade Calcareous Phosphate Rocks. J. Fert. Res. 44, 133-142. https://doi.org/10.1007/bf00750803

20 Ashraf, M. (2010). Reaction kinetics and mass transfer studies in selective leaching of low-grade calcareous phosphate rock. Doctor's thesis. Multan, Pakistan.

21 Raiymbekov, Y., Besterekov, U., Abdurazova, P., Nazarbek, U. \& Petropavlovskiy, I. (2021). Beneficiation of phosphatesiliceous slates via acetic acid. International Journal of Chemical Reaction Engineering, 19(11), 1187-1195. https://doi.org/10.1515/ijcre-2021-0071

22 Reed, S.J.B. (2008). Electron Microprobe Analysis and Scanning Electron Microscopy in Geology. Cambridge: University of Cambridge. https://doi.org/10.1017/CBO9780511610561

23 Voldman, G.M., \& Zelikman, A.N. (2003). Teoriia gidrometallurgicheskikh protsessov [Theory of hydrometallurgical processes]. Moscow: Intermet Engineering [in Russian].

24 Hatcher, L. (2013). Advanced Statistics in Research: Reading, Understanding, and Writing Up Data Analysis Results. Michigan: Shadow Finch Media LLC.

25 Martin, W.E. \& Bridgmon, K.D. (2012). Quantitative and Statistical Research Methods: From Hypothesis to Results 1st Edition. San Francisco: Jossey-Bass.

26 Davenport, W.G. \& King, M.J. (2006). Sulfuric Acid Manufacture. Analysis, Control and Optimization. Netherlands: Elsevier Science.

27 Guerra-Cossío, M.A., Lopez, J. R. G. \& Zaldivar-Cadena, A.A. (2017). Calcium sulfate: an alternative for environmentally friendly construction. 2nd International Conference on Bio-based Building Materials \& 1st Conference on ECOlogical valorisation of GRAnular and FIbrous materials (pp. 1-6). Clermont-Ferrand, France. https://doi.org/10.26168/icbbm2017.37

\section{Information about authors}

Raiymbekov Yerkebulan (corresponding author) - PhD-student, M.Auezov South Kazakhstan University, Department of Chemical Technology of Inorganic Substances, Tauke Khan Avenue, 5, 160000, Shymkent, Kazakhstan; e-mail: eplusr@bk.ru; https://orcid.org/0000-0002-2119-2406;

Besterekov Uilesbek - Doctor of Technical sciences, Professor, M.Auezov South Kazakhstan University, Department of Chemical Technology of Inorganic Substances, Tauke Khan Avenue, 5, 160000, Shymkent, Kazakhstan; e-mail: besterek80@mail.ru;

Abdurazova Perizat - PhD, Ass. Professor, M.Auezov South Kazakhstan University, Department of Chemical Technology of Inorganic Substances, Tauke Khan Avenue, 5, 160000, Shymkent, Kazakhstan; e-mail: abdurazova-p@ mail.ru, https://orcid.org/0000-0002-5244-7678; 
Nazarbek Ulzhalgas - PhD, Ass.Professor, M.Auezov South Kazakhstan University, Department of Chemical Technology of Inorganic Substances, Tauke Khan Avenue, 5, 160000, Shymkent, Kazakhstan; email: unazarbek@mail.ru, https://orcid.org/0000-0001-8890-8926;

Pochitalkina Irina - Doctor of Technical sciences, Professor, Department of Technology of Inorganic Substances and Electrochemical Processes, Miusskaya Square, 9, 125047, Moscow, Russia; e-mail: ipochitalkina@muctr.ru. 